\section{Abortion law}

I read the commentaryl on 'Abortion law: campaign groups and the quest for change' in the October 2006 issue of the Journal with interest. In general, it provides a very balanced overview of the different groups seeking change in UK abortion legislation, summarising the concerns of both pro-life and pro-choice organisations.

However, in his discussion and conclusions, Dr Vincent Argent ceases to be impartial and reveals his own prejudices, consistent with his position as Medical Director of bpas. He asserts that anti-abortion campaigners are seeking to "whittle away" at the legal provision of abortion until such time as they can prevent abortion taking place altogether. This is patently not true. At least two of the pro-life organisations cited are aiming to reform abortion legislation and to see it enforced properly, but do not seek to ban it altogether.

He then describes the sentiment that "the smaller and less well developed the fetus is, the less they feel uncomfortable about the idea of abortion" as a common-sense pragmatic view. He is thus implicitly labelling any who do not hold to this sentiment as lacking common sense.

Finally, in his conclusion, Dr Argent suggests that "the majority of women in the UK agree with those groups calling for change in the law to allow easier and earlier access and women's choice on abortion". On what evidence does he base this statement? The only evidence he alludes to is in the sentence "Other polls generally show support for earlier abortion on request and improved access".

He does mention a recent MORI poll, which claimed that $47 \%$ of women believe the legal time limit for abortion should be reduced from 24 weeks. But he makes no specific reference to the "other polls", which he claims show that the majority of women in the UK would like easier access to abortion.

Having read earlier in the commentary about the views of five large organisations that are prolife, it appears that many women would support either reduced access to abortion or stricter enforcement of the current abortion law as originally intended. I therefore find it difficult to believe Dr Argent's assertions without proper evidence to back them up.

Roxana Whelan, MRCGP, DFFP General Practitioner, Nottingham, UK and Regional Staffworker, Christian Medical Fellowship, UK.E-mail: roxanawhelan@ ntlworld.com

\section{Reference \\ Argent V. Abortion law: campaign groups and the quest for change. J Fam Plann Reprod Health Care 2006: 32: 215-217.}

\section{Reply}

Shortage of space in a journal always constrains the amount of material in any commentary. References to support the view that "other polls generally show support for earlier abortion on request and improved access"1 have been widely available. They include one on 'Women's perceptions of abortion law and practice in Britain'2 carried out by BMRB Social Research for Marie Stopes International. This showed that $88 \%$ of women believed that decisions about abortion should rest with the woman concerned and that $67 \%$ believed that abortion should be free on the National Health Service.

The State of the Nation poll by the Joseph Rowntree Reform Trust $^{3}$ found that $76 \%$ of the UK population were pro-choice. The Royal College of Obstetricians and Gynaecologists reported that one in three women have an abortion in their lifetime and that almost $90 \%$ of abortions take place in the first 12 weeks of pregnancy. ${ }^{4}$ These large numbers provide a practical demonstration of the wishes of women to have access to early abortion.
The argument about abortion on request is also widely debated. A woman has no right to terminate an unwanted pregnancy and must depend entirely on the opinions of two medical practitioners. This may well be seen by the public as out of step with the increasing priority given to a patient's right to make their own decisions about their medical treatment in other fields of medicine.

It is perhaps more important to try and reduce the need for abortion by focusing on the maintenance and improvement to the provision for contraception, particularly of long-acting methods. ${ }^{5}$ Health professionals, unfortunately, have little impact on the social changes required to increase the awareness of the risk of pregnancy from any act of sexual intercourse.

Vincent Argent, FRCOG, LLB

Consultant Obstetrician and Gynaecologist

(Lead in Sexual Health), Addenbrooke's

Cambridge University Teaching

Hospital, Cambridge, UK.

E-mail:vincent_argent@hotmail.com

\section{Gill Wakley, MD, FFFP}

Advisory Editor, Journal of Family Planning and Reproductive Health Care

\section{References}

V. Abortion law: campaign groups and the quest for change, J Fam Plann Reprod Health Care 2006; 32: 215-217.

women's Perceptions of Abortion Law and Practice in Britain, 2002: An Independent Survey for Marie Stopes Internation conducted by BMRB Social Research. London, UK: Marie Stopes International, 2002

3 ICM Poll. State of the Nation. York, UK: The Joseph Rowntree Reform Trust Ltd, 2004. http://www.jrrt.org. uk/ [Accessed 16 November].

Royal College of Obstetricians and Gynaecologists (RCOG). The Care of Women Requesting Induced Abortion. London, UK: RCOG Press, 2004. 5 Kishen M, Belfield T. Contraception in crisis. J Fam

\section{How can we reduce unintended \\ pregnancies?}

Unintended and unwanted pregnancy rates continue to rise in England and Wales. These rates largely translate into termination of pregnancies, the bulk of which occur in teenagers and in younger women aged 25 years or less. 1 These high rates occur against the background of free contraceptive services. It would appear then that apathy to the use of contraception by women is an important contributory factor. It is possible also that the wrong choices regarding contraception are being made by women and their doctors. There is evidence that about $50 \%$ of all pregnancies are unplanned, and in early or late reproductive life such pregnancy is commonly unwanted and is likely to be terminated. ${ }^{2}$

This makes the proper use of effective contraception the most important intervention in the prevention of unintended pregnancies and hence unwanted pregnancies. There is evidence that most women seeking termination of pregnancy are not using contraception at all, using condoms which depend largely on proper user application for effectiveness, or using ineffective contraception by haphazardly taking the oral contraceptive pill. ${ }^{3}$ Such women also recognise that the contraceptive of choice for them is one that they do not have to remember to take. ${ }^{4}$ Long-acting reversible contraceptives (LARCs) would be the contraceptives of choice for these women. These are the depot medroxyprogesterone acetate injection (DepoProvera $\left.{ }^{\circledR}\right)$, the progestogen subdermal implant $\left(\right.$ Implanon $\left.{ }^{\circledR}\right)$, progestogen intrauterine system $\left(\right.$ Mirena $\left.{ }^{\circledR}\right)$ and copper intrauterine devices.

The guidelines by the National Institute for Health and Clinical Excellence (NICE) ${ }^{5}$ endorsing LARCs as the contraceptive methods of choice is to be commended and it is hoped that these can make an impact in reducing unintended or unplanned pregnancy rates and hence unwanted pregnancies and termination of pregnancy rates. For this reduction in unwanted pregnancies to occur, the guideline needs to be embraced wholeheartedly by all practitioners especially in primary care and family planning clinics, where the bulk of contraceptive care in the UK is provided. The guideline makes the case eloquently in terms of efficacy and costeffectiveness. For the younger woman or teenager the case for using a LARC cannot be overemphasised as sexual intercourse commonly is unplanned and may also occur under the influence of alcohol. This group of women also lead busy and some times chaotic lives - a scenario lacking in the orderliness, discipline and the forward planning necessary for the successful use of a daily applied method of contraception such as the pill or condoms

All family planning clinics and general practice surgeries should, as a matter of urgency, become conversant with the insertion or administration techniques for these LARCs. The oral contraceptive pill should be prescribed only where short-term contraception is required (e.g. where a pregnancy is desired within 3 months or less). Condom use needs to be promoted, mainly as protection against sexually transmitted infections, and LARC as protection against pregnancy.

Umo I Esen, LLM, FRCOG

Consultant Obstetrician and Gynaecologist, South Tyneside NHS Foundation Trust,

South Shields, UK.

E-mail:Umo.Esen@sthct.nhs.uk

\section{References}

Department of Health. Abortion Statistics, England and Wales: 2004. (Statistical Bulletin) London, UK: (Stath, 2005

2 Esen UI. Prolonged interpregnancy interval: a marker for non-use of contraception and unplanne pregnancy. J Obstet Gynaecol 1996; 16: 493-495. contraceptive care: can we reduce the incidence of repeat abortions? J Fam Plann Reprod Health Care 2001; 27 : 77-80.

4 Fisher WA, Singh SS, Shuper PA, Carey M, Otchet F, MacLean-Brine D, et al. Characteristics of women undergoing repeat induced abortion. CMAJ 2005; 172:

637-641. Commissioned by the National Institute for Health and Clinical Excellence (NICE). London, UK: RCOG Press, pdf [Accessed 16 November 2006].

\section{Increase in IUD expulsions}

I read with interest the letter from Frank Hawkins and Nanas Callander in the October 2006 issue of the Journal. ${ }^{1}$

A few years back I published a similar letter in the Journal,2 which was followed by a lot of correspondence over a period of a year and the journal editor had to stop further correspondence with the promise of publishing a special review article on the topic.

Those days it was Gyne-T Safe ${ }^{\circledR}$ intrauterine device (IUD). I had problems like other displacement with the thread too long or expulsion. After much trial and error with the plastic model I felt there was something wrong with the design and I approached the manufacturer, however they did not even have the courtesy to acknowledge my letter. After my letter was published in the Journal ${ }^{2}$ the company sent a representative to discuss the issue.

What I suggested was that the tube holding the IUD was rather snug fitting and also that the introducer rod was short of the outer opening. As a result the IUD didn't emerge completely from the tube and during removal of the tube the IUD was pulled down with it. I therefore used to line up the rod a few millimetres just above the top end of the tube and cut the tube with scissors, which ends at the lower end of the rod, like a stopper above ring. After that it was very easy to load the IUD, introduce it and pull the tube up to 